\title{
The Concept of Zonation of Sapangka and Luak-lareh in the Performance of Ulu Ambek in Pariaman Minangkabau
}

\author{
Asrill $^{1 *} \quad$ Adjuoktoza Rovylendes ${ }^{2} \quad$ Dafit Saputra ${ }^{1}$ \\ 1.Karawitan Department, Faculty of Performing Arts ISI Padangpanjang \\ 2.Dance Department, Faculty of Performing Arts ISI Padangpanjang
}

\begin{abstract}
The concept of sapangka and luak-lareh refers to the grouping of contestants and the division of territory in the performance of ulu ambek. The sapangka is the host organizing the performance, and consists of several ulu ambek communities from a number of different nagari (villages). The ulu ambek communities of the sapangka are joined by the social, cultural, and regional bonds of a lareh. Lareh is the name given to a traditional government area controlled by ninik mamak (traditional elders), based on the territorial division that underlies the zonation in an ulu ambek performance. Luak-lareh refers to the ulu ambek contestants who come from lareh outside the lareh sapangka (host zonation). The goal of this research is to describe, discuss, and analyze the division and work method of ulu ambek performance in the zonation system of sapangka and luak-lareh. The research results show that the zonation of sapangka and luak-lareh has been established over a long period of time, based on social, cultural and emotional bonds between nagari, so that the performance of ulu ambek is well arranged in a system that has been preserved until the present day.
\end{abstract}

Keywords: sapangka, lareh, luak-lareh, zonation, and ulu ambek.

DOI: $10.7176 / \mathrm{ADS} / 94-04$

Publication date:July $31^{\text {st }} 2021$

\section{Introduction}

Ulu ambek is a customary ritual traditional art of the Pariaman community which has become a symbol of greatness for traditional leaders or headmen (ninik mamak) in Pariaman. The symbolization of greatness of the ninik mamak in the Pariaman community is expressed through the important attributes in ulu ambek performances, which represent this greatness both denotatively and connotatively (Astil Muchtar, 2015: xiii). An ulu ambek performance is an exhibition performed by a pair of ulu ambek players in the form of an "attack" (ulua) and "rebuttal" (ambek), without any direct physical contact (Asril Muchtar, 2011a). Ulu ambek is a type of martial art which is based on Minangkabau silat. At every event of an ulu ambek performance, tens of ulu ambek players take part. They include the sapangka (host community) and other invited communities from outside the area. The ulu ambek sapangka community consists of several ulu ambek communities that belong to the same area, or lareh. The invited communities are known as luak-lareh groups. The areas designated as the sapangka and luak-lareh are made up of a number of nagari (villages), bound by common historical, customary/cultural, social and emotional ties.

The bonds that form the sapangka and luak-lareh communities define the zonation of territory in ulu ambek. Zonation is the division of territory into a number of sections in accordance with the function and objectives of its management (KBBI, 2014: 1572). There are currently five active areas of lareh zonation: Lareh Duo Kali Sabaleh, Lareh Anam Lingkuang, Lareh VII Koto, Lareh Lubuk Aluang, and Lareh Nan Sabarih. There are also a number of other inactive lareh zonation areas, such as Lareh Aia Pampan, Lareh V Koto, and Lareh XII Koto.

The zonation of sapangka and luak-lareh in the performance of ulu ambek determines the locus of the contest and is a unique phenomenon in this traditional art of Pariaman, Minangkabau. Traditional elders of the Pariaman community have designated the sapangka and luak-lareh territories along with the division and work mechanism of the performance of ulu ambek in a system. This is an interesting phenomenon to study in order to reveal the traditional, cultural, social, and emotional bonds between different nagari, to establish the ulu ambek zonation that has become a customary conventional rule in the Pariaman community.

\section{Method}

The collection of data related to the concept of zonation of sapangka and luak-lareh in the performance of ulu ambek, and the division of its zonation, was carried out in all existing areas of lareh zonation, specifically in lareh that are still active in ulu ambek performance. In each lareh, information was gathered about all the nagari belonging to the particular lareh as well as the nagari that participate in ulu ambek performances. This mapping and grouping of nagari to establish the areas of zonation of sapangka and luak-lareh was an important step because not all nagari in a particular lareh zonation are involved in ulu ambek performance. A field study was undertaken to obtain data about the territory of a sapangka community and lareh, which is also luak-lareh for communities in other areas. Data was also collected about the specific role, function, and status of each nagari or ulu ambek group in a sapangka community, as well as the general role, function, and status of each sapangka 
and luak-lareh in the ulu ambek performance system. It was essential for the researchers to visit each zonation area of sapangka and luak-lareh in order to observe directly which groups are part of the sapangka and which groups belong to the luak-lareh. As Schechner explains, in performance research, the involvement of the researcher in every event of performance is vital (Schechner, 2013). In connection with the present context of $u l u$ ambek performance, due to the fact that the research was carried out during the covid-19 pandemic, not many of the nagari were holding any ulu ambek performances. In addition to concerns about exposure to the corona virus, local leaders and those wishing to host an ulu ambek performance had difficulty obtaining government permission to hold a performance. Ulu ambek performances involve the gathering of large numbers of people over a period of 3-4 days, and would therefore have a potentially large impact on the spread of the corona virus within the community.

\section{Results and Discussion}

\subsection{Sapangka and Lareh}

In the context of ulu ambek, the discussion about the concepts of sapangka and lareh show that the two concepts are closely related, since they both have a traditional work mechanism that is associated with other areas of zonation. Every sapangka is in a particular lareh; every lareh has several nagari which can function as sapangka. The work mechanism applied in the event of an ulu ambek performance, for the nagari that belong to a particular lareh and are designated or offer themselves to become the sapangka, is agreed upon in consensus by the entire ulu ambek community in the particular lareh.

\section{Sapangka}

The general meaning of sapangka is the host or the party organizing an activity or event. This definition applies universally and is understood extensively in the Minangkabau community. In the context of ulu ambek, sapangka refers to the party organizing or hosting an ulu ambek performance. This party is the nagari and the different elements of society within the nagari. These elements include the ninik mamak, leaders of the nagari and korong (hamlet), community figures, religious leaders, and young people. The ninik mamak play an important role in the performance of ulu ambek because ulu ambek is a traditional ritual performance that symbolizes the greatness of the ninik mamak. An ulu ambek performance is an expression of appreciation and respect for the ninik mamak as the holders of tradition. As stated in the traditional Pariaman phrase, ulu ambek is: "suntiang ninik mamak, pamainan nan mudo-mudo" (the crown or greatness of the ninik mamak, but performed by young people). Ulu ambek is performed by young people, with rules of etiquette that honor the greatness of the ninik mamak (Asril Muchtar, 2010).

In practice, the active role of the ninik mamak in the performance of ulu ambek is carried out by the kapalo mudo, or the person in charge of organizing all the activities related to ulu ambek involving young people in the community. In the context of ulu ambek, the kapalo mudo serves as the representative or extension of the ninik mamak, by performing the traditional ulu ambek ritual. This means that everything associated with ulu ambek, from the preparations to the accessories, and other supporting elements of the performance, the invitations, organization of the performance until its completion, is carried out by the kapalo mudo with the assistance of young people from the community and those active in the ulu ambek community. Everything the kapalo mudo does must be with the permission and approval of the ninik mamak. The kapalo mudo is one of the customary leaders who is influential in the community, especially in connection with the traditional activities and customs that prevail in a nagari. The ninik mamak watch every stage of the activity carefully to make sure nothing will impair the authority and greatness of the ninik mamak, including both the ninik mamak from their own nagari and those who are invited as ulu ambek guests from luak-lareh. The ninik mamak encourage the ulu ambek players to perform with elegance and to their best ability to preserve the good image of the nagari. The basic principles that must be upheld in ulu ambek, as mentioned by Yulinis (2015: 267), are: tageh, a balance between power, gentleness, ingenuity, vivacity, and flexibility in play; and bataratik, behaving with courtesy. Asril Muchtar (2015) explains further that there is a need for vigilance and caution; ulu ambek has wisely taught values of sportiveness, vigilance, respect, and politeness to the ulu ambek players.

Other elements of the community, such as local leaders and community figures, or 'intellectuals', along with religious leaders, each play a specific role in accordance with their position in the ulu ambek tradition. The intellectuals and religious leaders take their place inside the performance arena, seated on top of the laga-laga (stage) with the ninik mamak, to oversee the implementation of the ulu ambek performance. They preside over the whole ulu ambek performance until the end, to ensure it stays on the right track. Meanwhile, the young people under the control of the kapalo mudo have the task of performing the ulu ambek in their capacity as the sapangka, in competition against other ulu ambek players from luak-lareh.

The nagari that is acting as the sapangka cannot simply organize the entire ulu ambek performance by itself. It joins together with other nagari in the same lareh. The other nagari join together and act as the sapangka to face up against the invited ulu ambek players. They share the same social, cultural, and emotional responsibilities. 
The social, cultural, and emotional connection between all the different nagari in a particular lareh is a longstanding tradition in the context of ulu ambek. This is stressed by Zulkifli Tajun, the kapalo mudo in the village of Marunggi Kurai Taji, and an active member of the ulu ambek community: "If there is a mistake that leads to an accident in relation to the ulu ambek tradition, the sense of shame is borne together by all the nagari in a single lareh" (interview, 8 November 2020 in Marunggi Kurai Taji).

\section{Lareh}

In the Minangkabau language, the word lareh is often pronounced as 'laras', or alternatively it may be written as 'laras' but pronounced as 'lareh'. For example, laras koto piliang is more often pronounced by the Minangkabau people as lareh koto piliang. Despite the difference in pronunciation, lareh, or laras, has the same meaning. Bapayuang (2015) in the Minangkabau dictionary 'Kamus Baso Minangkabau', writes that lareh means: laras; an original term for territorial division. Meanwhile, the word lareh is not found in the Indonesian dictionary, Kamus Besar Bahasa Indonesia, but one of the meanings listed for the word laras is the same as the definition of lareh. "Laras means a district in Minangkabau, the basis of the traditional government system" (KBBI, 2014: 791).

The word lareh, or laras, does not always refer to an area or district. The most prominent meaning of the word lareh is in fact related to the government system followed by all nagari in Minangkabau. This meaning of lareh is used in the terms Lareh Bodi Caniago and Lareh Koto Piliang. Lareh Koto Piliang was initiated by Datuk Ketumanggungan, while Lareh Bodi Caniago was initiated by Datuk Perpatih Nan Sabatang, and the two lareh together are referred to as lareh nan duo. These two lareh have differences in their government systems. Koto Piliang is more aristocratic in nature while Bodi Caniago is democratic (Navis, 1984). A number of other writers have also expressed a similar view to Navis. They include Amir Sjarifuddin Tj.A (2011), Hadler (2010), Zubir (2010), Kemal (2009), Dobbin (2008), Graves (2007), Kato (2005), and Mansoer, et al. (1970). The reason for mentioning this is only for the purpose of comparison. The meaning of lareh as used in this article will be explained below.

Lareh, or laras, according to the definition in the Minangkabau and Indonesian dictionaries, Kamus Baso Minangkabau and KBBI, is the division of a territory or district, and this is the definition of lareh used in this article. Essentially, the meaning of lareh is the affiliation of two or more nagari due to economic or political reasons and for ease of control by the Dutch. According to Gusti Asnan (2007: 86-87, 96): "The formation of a 'kelarasan' system was a policy of the Dutch colonial government. The Dutch colonial government frequently initiated change in the models and areas of control of the governmental system in Minangkabau during the time of its occupation. Administratively, Inlandsche Bestuur, or "the government of urang awak (Minangkabau people)" in the Residency of West Sumatra, was divided by the Dutch into two Hoofdafdeelingen, namely: Hoofdafdeeling van Padang and Hoofdafdeeling van Minangkabau. Each Hoofdafdeeling was divided further into a number of Regentschap, and each Regentschap was subdivided into a number of lower administrative units, namely: 1) Kelarasan or Districten, 2) Nagari, and 3) Dusun (Hamlet). A Kelarasan was headed by a Kepala Laras. The Kepala Laras was also sometimes referred to as Tuanku Lareh or Angku Lareh. Each kelarasan was divided into a number of kenagarian (dorpen), headed by a Kepala Nagari (dorphoofd), while the head of a dusun was known as the pengulu.

Nagari and kelarasan were subject to change depending on the political developments and policies of the Dutch colonial government. Asnan (2007: 100-101) writes:

"The Dutch could easily create and remove nagari and kelarasan based on the economic and political interests of the community. This included the fusion of a number of kelarasan or districts to form a new district known by the name of kademangan. A kademangan was headed by a demang, known in the Minangkabau community as Angku Damang. In the area of Pariaman, for example, two kademangan were established in 1913, namely Kademangan Pariaman and Kademangan Ulakan. Subsequently, in 1935, the Dutch colonial government changed the kademangan districts in Pariaman once again to become: 1) Kademangan Lubuk Alung with two Asisten Demang, namely the districts of Lubuk Aluang and Kayu Tanam-VII Koto; 2) Kademangan Pariaman with two Asisten Demang, namely the districts of Pariaman and Sungai Limau."

By the end of the $19^{\text {th }}$ century, 116 kelarasan had been established by the Dutch colonial government, 7 of which were in the Afdeeling of Pariaman (at the level of a Regency), namely: Pariaman, Manggung, V Koto, Pilubang, Ulakan, VII Koto, and Kayu Tanam. The kelarasan established by the Dutch in Pariaman were founded strongly on political and economic interests (Asnan, 2007). If the kelarasan formed by the Dutch were used as a point of departure for establishing the lareh districts of ulu ambek, it would not be appropriate, since the Dutch interests were quite different from the traditional and cultural interests of the Pariaman community. However, the basic principle of lareh being a combination of a number of nagari is also found in lareh ulu ambek. In relation to the ulu ambek tradition, there are eight lareh in Pariaman: 1) Lareh Duo Kali Sabaleh, 2) Lareh Anam Lingkuang, 3) Lareh VII Koto, 4) Lareh Lubuak Aluang, 5) Lareh Nan Sabarih, 6) Lareh V Koto, 7) 
Lareh XII Koto, 8) Lareh Air Pampan. However, nowadays there are only five lareh still active in the performance of ulu ambek, namely: Lareh Duo Kali Sabaleh, Lareh Anam Lingkuang, Lareh VII Koto, Lareh Lubuak Aluang, and Lareh Nan Sabarih.

\subsection{Luak-lareh}

In the Minangkabau dictionary, Kamus Baso Minangkabau, written by Yus Magek Bapayuang (2015), the word luak means: a traditional administrative area governed by ninik mamak. In this case, the examples given of traditional administrative areas in Minangakabau are Luak Tanah, Luak Agam, and Luak 50 Koto. This dictionary does not include the word luhak as an alternative spelling with the same meaning as luak, which is why Bapayuang writes Luak Tanah Data, not Luhak Tanah Data. Nevertheless, the word 'luhak' is also generally understood and used by the Minangkabau people, as in the example Luhak Tanah Data. This can be compared with the word luak in the Indonesian dictionary, Kamus Besar Bahasa Indonesia, which is defined as district; luhak. The word luak has the same meaning as luhak (KBBI, 2014: 843, 845). Luak, according to Bapayuang (2015: 255), in addition to meaning district, has the additional meaning of 'reduced', 'decreased', and 'apart from'.

In lexical terms, the term luak-lareh consists of the words luak and lareh. In the context of the ulu ambek tradition, the words luak and lareh have a slightly different definition from that in the dictionary, as mentioned above, as well as a different meaning. The words luak and lareh may be joined together as luak-lareh, or simply as lareh, while the word luak itself is seldom used as in the definition of the Baso Minangkabau and KBBI dictionaries.

In the context of this article, the meaning of luak-lareh is the invited guests from other districts outside the area of the sapangka, as regulated according to a consensus of the ninik mamak of Pariaman. The sapangka area consists of a number of nagari that have historical, traditional, cultural, social, and emotional ties. Likewise, the luak-lareh consists of a number of nagari with similar historical, traditional, cultural, and emotional ties, in the same way as the sapangka. If this is connected with the meaning of the word luak in the Kamus Baso Minangkabau dictionary, specifically the alternative meaning 'apart from', in the context of ulu ambek, the word luak can be understood to mean 'apart from' lareh, and this is in fact the intended meaning in the context of the ulu ambek tradition.

The ties that bind together a sapangka or luak-lareh group are manifested in the zonation of territory in ulu ambek. Zonation is the division of territory into a number of sections in accordance with its function and objectives (KBBI, 2014: 1572). Every zonation of lareh can function as the sapangka and may also function as luak-lareh. When the nagari in a particular lareh become the sapangka, the other lareh will become the luaklareh.

\subsection{Sapangka and Luak-lareh pre-Performance}

Together, the sapangka are responsible for deciding when the ulu ambek performance will take place, preparing or repairing the laga-laga (the special stage used for the ulu ambek performance), conveying their intentions to the nagari in the same lareh, inviting guests from luak-lareh, selecting the people who will perform the role of janang (the mediator for the performance), preparing the ulu ambek players, forming the parik paga (security team), and holding the ulu ambek performance. The responsibilities of the sapangka are not only borne by the nagari hosting the performance but are also shared by colleagues from other nagari in the same lareh. All the nagari in the lareh play an active part in the preparations to ensure that the ulu ambek performance runs smoothly, and they also put forward their ulu ambek players to perform in the role of sapangka, to compete against the ulu ambek players from luak-lareh. The ninik mamak carefully guide and supervise in detail every task carried out so that none of the traditional conventions and requirements are missed. The ninik mamak are there to offer suggestions and advice, and to accommodate requests about anything that needs to be done, especially in connection with the symbolization of their greatness. This is expressed in the traditional phrase, " $k a$ pai tampek batanyo, ka pulang tampek babarito" (before going out or carrying out any task, first ask the ninik mamak, when a job is complete, report back to the ninik mamak).

The kapalo mudo has the extensive job of production and stage manager for the ulu ambek performance. Together with younger members of the community, he invites ulu ambek groups from luak-lareh. The ulu ambek groups from luak-lareh welcome the kapalo mudo in their own areas, and usually the laga-laga serves as the best place for the meeting. The ulu ambek communities from luak-lareh display courtesy and deference when receiving the invitation by welcoming the kapalo mudo to their laga-laga. This is a way of showing respect and positioning the matter in accordance with its cultural context. It also shows the high level of respect for the $u l u$ ambek as a symbol of greatness of the ninik mamak. The laga-laga is deemed the appropriate place for anything associated with ulu ambek. The ulu ambek communities from luak-lareh hold discussions, in which they decide to accept the invitation from the sapangka, as long as all the circumstances are in their favor: they must receive permission from the ninik mamak, the anak mudo (ulu ambek players) must be ready and willing to perform, 
health conditions must be met, and so on.

The ulu ambek communities from each luak-lareh area arrive at the village of the sapangka based on a prior agreement. There is no commitment for all the groups to arrive at the venue at the same time. In general the teams arrive after midnight. When an ulu ambek team from one particular luak-lareh arrives at the performance venue, before entering the arena, the players yell out a part of the dampeang melody: the musical accompaniment for the ulu ambek. The purpose of this is to announce their arrival. Their yells and the dampeang are welcomed by the sapangka by responding with their own dampeang yells, before receiving them in the appropriate customary manner. This happens every time a different ulu ambek community arrives. As the invited guests from luak-lareh arrive, they are placed in aisles to the left and right, and behind the laga-laga, according to the traditional rules that apply. This means that each invited luak-lareh group has its own particular seating area in the laga-laga, based on an agreement established by the ninik mamak and ulu ambek elders.

\subsection{Sapangka and Luak-lareh in a Performance Context}

The ulu ambek luak-lareh groups that arrived earlier in the night are requested respectfully by the kapalo mudo sapangka to present a performance of randai ulu ambek (a section of the ulu ambek performance). This also applies to the other ulu ambek groups, all of which are asked to perform randai ulu ambek. The main ulu ambek performance (a contest between a pair of ulu ambek players) takes place the following day, from late morning until evening. For the ulu ambek luak-lareh communities, the ulu ambek performance is based on negotiations that take place on the laga-laga, involving the ninik mamak and all the main elements related to the ulu ambek performance. The ulu ambek communities that arrive earlier and have teenage ulu ambek players are given priority to perform first. The teenage ulu ambek players are given the opportunity to perform first to motivate them and also so that they will be able to watch the subsequent performances by adult groups. For all ulu ambek communities, these teenagers are the cadres who will continue to become future ulu ambek players.

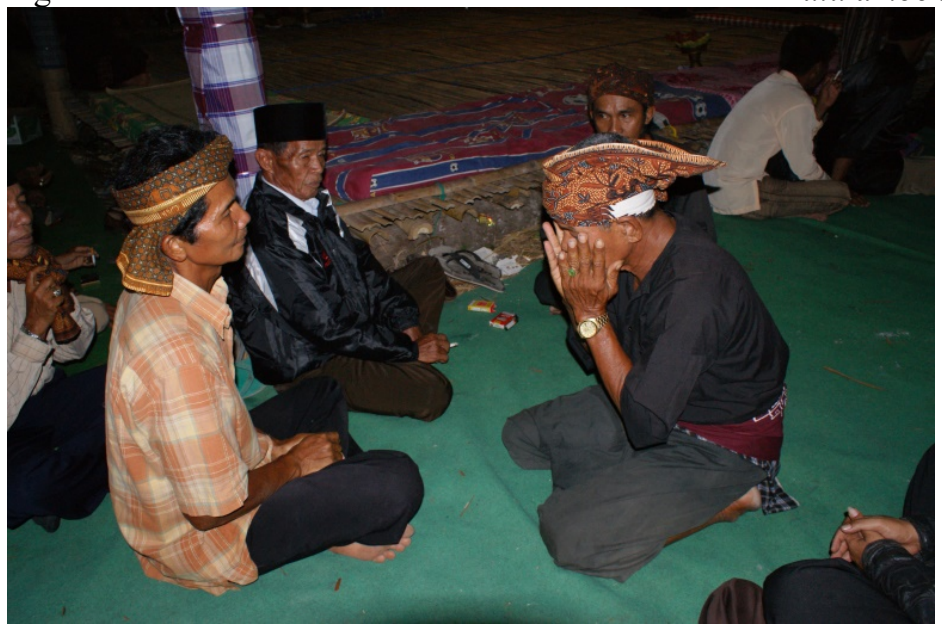

Figure 1. Every ulu ambek player who is about to perform must first greet the elders and other ulu ambek players from his own lareh community who are seated in the aisles. When he enters the laga-laga stage, the player also greets all the ninik mamak, religious leaders, and intellectuals seated on the laga-laga in the same way. (Photo: Asril Muchtar)

At every ulu ambek performance, the contestants competing consist only of the ulu ambek teams from the sapangka group and the luak-lareh. Out of all the active lareh zonations, one functions as the sapangka and the others are the opponents or luak-lareh. In the ulu ambek tradition, there has never been an ulu ambek performance in which the competing pairs are both from the luak-lareh community or both from the sapangka community. The performance will always be between ulu ambek sapangka players and ulu ambek players from luak-lareh. For example, if nagari Tandikek and other nagari in the Lareh VII Koto zonation are the sapangka, their opponents will be ulu ambek groups from nagari in the zonations of Lareh Duo Kali Sabaleh, Lareh Anam Lingkuang, Lareh Lubuak Aluang, and Lareh Nan Sabarih. Hence, the there are clearly defined boundaries in the zonations between the sapangka and luak-lareh in the performance of ulu ambek. This is illustrated in the diagram below. 


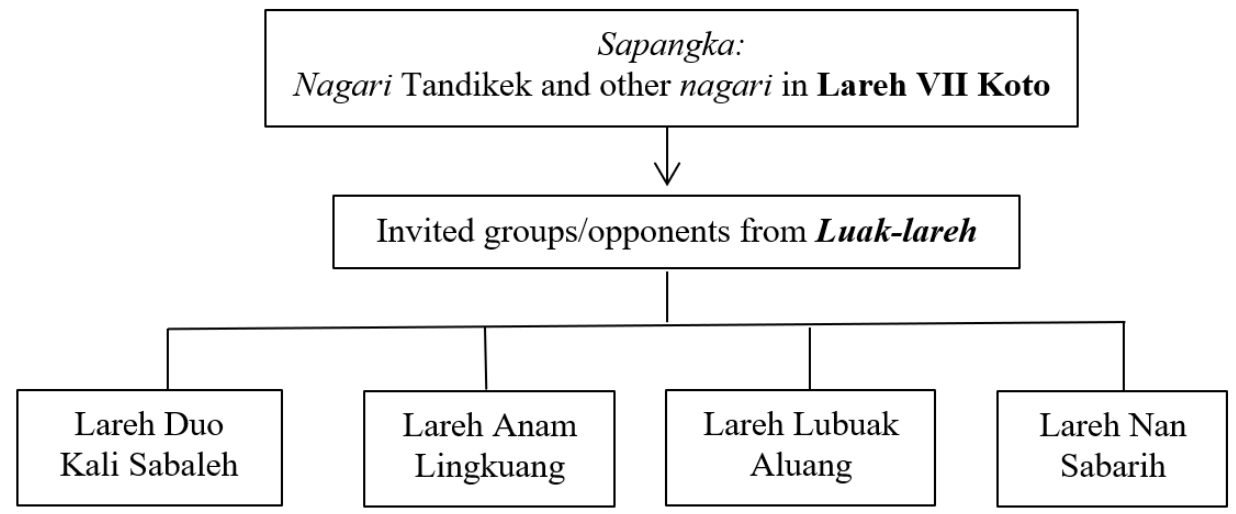

Figure 2. Diagram showing sapangka and luak-lareh in an ulu ambek performance.

Nevertheless, in certain cases two lareh may join together to act as the sapangka. For example, Lareh Duo Kali Sabaleh could join with Lareh Anam Lingkuang to be the sapangka. This may occur because at the present time, in Lareh Duo Kali Sabaleh there are only two nagari participating actively in ulu ambek activities, namely Kapalo Hilalang and Sicincin. There are actually five nagari in this lareh but the other three nagari do not have any ulu ambek players so the total number of ulu ambek players is not enough to compete against the ulu ambek players from luak-lareh, and this is why they request the assistance of Lareh Anam Lingkuang. In addition, there are very close social, cultural, and kinship ties between Lareh Duo Kali Sabaleh and Lareh Anam Lingkuang, so emotionally and customarily, the two lareh lend each other their ulu ambek players to join together and form a sapangka.

Ulu ambek performances are directed by a janang, who guides and regulates the performance. Each performance lasts about 7-10 minutes. The players take up their position, with the sapangka player at the front and the invited player, or alek standing inside. The ulu ambek sapangka player has the role of making the first attack, while the role of the luak-lareh player is to rebut or block the attack. The first movement performed by both players is a display of deference and apology to all those present. This is compulsory for all ulu ambek players. As they listen to the text and the dampeang melody, the music that accompanies the ulu ambek performance, they continue to move cautiously, waiting for a certain code or text, at which moment they immediately take up their position and become involved in the performance, interacting without any direct contact. About half way through the performance, the janang instructs the ulu ambek players to switch position so that the ulu ambek sapangka becomes the blocker and the ulu ambek luak-lareh becomes the attacker. Throughout the duration of the performance, the janang closely observes both ulu ambek players. If one of them begins to play too roughly or to endanger his opponent, the janang gives a warning, by uttering the words "elokelok main" (please play nicely).

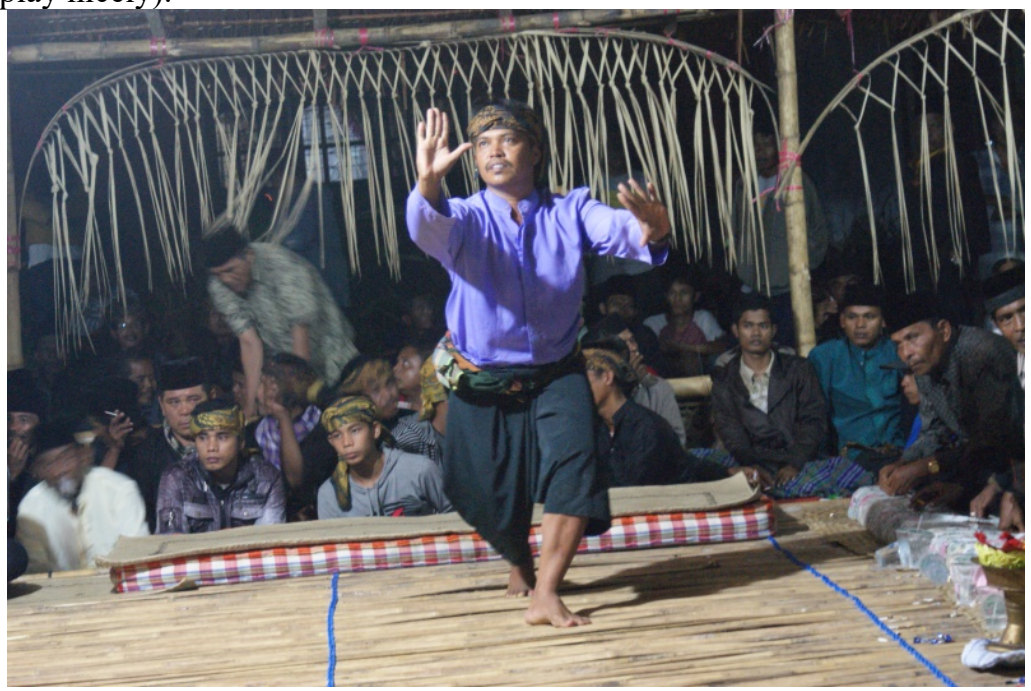

Figure 3. An example of the ulu ambek sapangka player performing the first role as the 'pe-ulua' (attacker). (Photo: Asril Muchtar). 


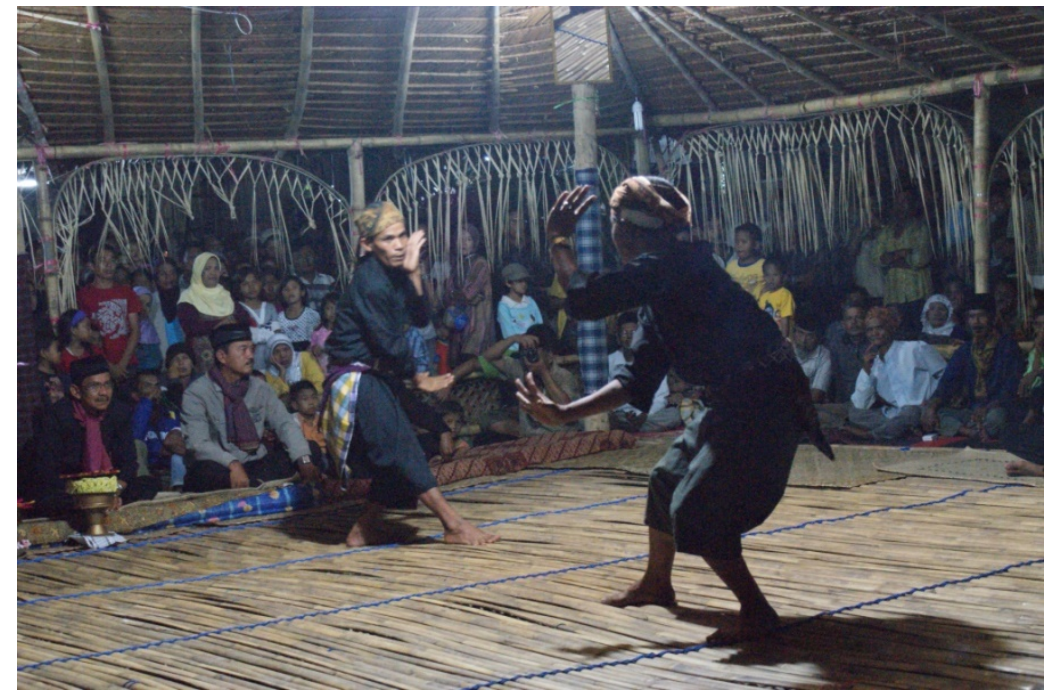

Figure 4. An ulu ambek performance taking place at night appears more visually artistic and aesthetic from the aspect of the audience. (Photo: Asril Muchtar)

The ulu ambek players who perform, both from the sapangka group and the luak-lareh community, take heed of the calls and warnings of the janang. If the play starts to become dangerous, the janang has the right to stop the performance. The janang is given the mandate by the ninik mamak to lead and direct the ulu ambek performance with a high sense of authority and responsibility. If chaos or confusion arises as a result of the janang's negligence, that particular janang will not be used again in future performances.

\section{Conclusion}

Zonation of the sapangka, lareh, and luak lareh in the tradition of ulu ambek performance is a standard concept that has been implemented since long ago. The sapangka is the host who organizes an event of ulu ambek performance together with the nagari that belong to the same lareh and are bound to each other by common responsibilities and social, cultural, and emotional or spiritual ties. The zonation of the sapangka is the joint territory of a number of nagari, known as a lareh. The zonation of the sapangka is the zonation of the lareh. The luak-lareh zonation is a concept referring to the location outside the sapangka territory which becomes the opponent. The luak-lareh zonation will emerge by itself whenever a particular lareh holds an ulu ambek performance. Every lareh can be the sapangka, and will instead become the luak-lareh when not acting as the sapangka. The real zonation is in fact the lareh, namely Lareh Dua Kali Sabaleh, Lareh Anam Lingkuang, Lareh VII Koto, Lareh Lubuak Lubuak Aluang, Lareh Nan Sabarih, Lareh V Koto, Lareh Aia Pampan, and Lareh XII Koto. There is no particular lareh that is specifically designated as luak-lareh. This zonation will appear when one of the lareh becomes the sapangka. The zonation of the sapangka, lareh, and luak-lareh has been established for a long period of time, based on social, cultural, and emotional bonds between nagari, which means the performance of ulu ambek is well arranged in a system that has been preserved until the present day.

\section{References}

Asnan, Gusti. (2006), Pemerintahan Sumatra Barat dari VOC Hingga Reformasi. Yogyakarta: Citra Pustaka.

Bapayuang, Yos Magek. (2015), Kamus Baso Minang. Jakarta: Mutiara Sumber Ilmu.

Dobbin, Christine. (2008), Gejolak Ekonomi, Kebangkitan Islam dan Gerakan Padri Minangkabau 1784-1874. Depok: Komunitas Bambu.

Garves, Elizabeth E. (2007), Asal-Usul Elit Minangkabau Modern: Respons terhadap Kolonial Belanda Abad $X I X / X X$. Jakarta: Yayasan Obor Indonesia.

Hadler, Jeffrey. (2010), Sengketa Tiada Putus: Matriarkat, Reformisme Islam, dan Kolonialisme di Minangkabau. Jakarta: Freedom Institute.

Kahin, Audrey. (2008), Dari Pemberontakan ke Integrasi: Sumatra Barat dan Politik Indonesia 1926-1998. Jakarta: Yayasan Obor Indonesia.

Kato, Tsuyoshi. (2005), Adat Minangkabau dan Merantau dalam Perspektif Sejarah. Jakarta: Balai Pustaka.

Kemal, Iskandar. (2009), Pemerintahan Nagari Mianangkabau dan Perkembangannya: Tinjauan tentang Kerapatan Adat. Yogyakarta: Graha Ilmu.

Mansoer, MD., et al. (1970), Sejarah Minangkabau. Jakarta: Bhratara.

Muchtar, Asril. (2015), "Ulu Ambek: Representasi Simbolik Kebesaran Pangulu dalam Masyarakat Pariaman," Foreword in Yulinis, Ulu Ambek: Relasi Kuasa atas Tari Tradisional Minangkabau. Yogyakarta: Media Kreativa. 
Muchtar, Asril. (2011a, 8 May 2011), “Ulu Ambek, Alau Ambek, Lu Ambek?” Posmetro Minggu.

Muchtar, Asril. (2011b,15 May 2011), "Ulu Ambek dalam Melintas Waktu," Posmetro Minggu.

Muchtar, Asril. (2011c, 22 May 2011), "Ulu Ambek, Seni Tradisi yang Menjunjung Nilai Sopan Santun dan Sportivitas," Posmetro Minggu.

Putra, Dilmai., Koes Yuliadi, dan Wilma Sriwulan (2016), "Ulu Ambek: Sebuah Pertaruhan Nilai," in Jurnal Bercadik, Vol. 3, No. 2, October, pp. 124-134.

Tim Redaksi. (2014), Kamus Besar Bahasa Indonesia. Fourth Edition. Jakarta: Gramedia Pustaka Utama. Schechner, Richard. (2013). Performance Studies: an Introduction. London: Routledge.

Sjarifoedin Tj. A, Amir. (2011), Minangkabau: dari Dinasti Iskandar Zulkarnaen Sampai Tuanku Imam Bonjol. Jakarta: Gria Media Prima.

Yulinis. (2015). Ulu Ambek: Relasi Kuasa atas Tari Tradisional Minangkabau. Yogyakarta: Media Kreativa. Zubir, Zayardam. (2010), Budaya Konflik dan Jaringan Kekerasan. Yogyakarta: INSISTPress. 